\title{
St Bartholomew's Hospital and Medical School: Department of Nuclear Medicine
}

\author{
Keith Britton
}

\subsection{Personal Reflections}

It was started by the Nobel prize-winning Professor Sir Joseph Rotblatt in 1960 as a Radioisotope department with Ms McAlister and Mr Laurie Hawkins as Physicists. I was appointed by the Chief of Radiology Dr Ian Kelsy-Fry as Consultant Physician in charge of the Nuclear Medicine Department in 1976. My aim was to set up an open, friendly and welcoming clinical, teaching and research department in spite of the poor physical environment and initially only one gamma camera. It was mainly equipped through various grants including one from the St Barts Trustees and not by the NHS. I was also appointed as Consultant Physician in acute General Medicine with ward beds, 'on take' twice a week, Outpatients and Hypertension Clinic and with students to teach. After I was made Professor of Nuclear Medicine, I continued with the Hypertension Clinic but with no further ward duties. We had excellent Physicist support with Messrs Alex Elliot, Cyril Nimmon, Melvyn Carroll, Ravin Sobnack and for therapy Ms Ro Foley; and innovative Pharmacy support with Mr Stephen Mather and Mr Kishor Solanki and their staff. Mr Jagdish Mistry led the dedicated technical staff with Ms Nishamalie Fenando. We introduced and were the first to use the Hermes system in the UK.

The three main influences that helped determine the teaching, research and staffing were the International Atomic Energy Agency, IAEA, the Imperial Cancer Research Fund, ICRF, later renamed Cancer Research UK and the European Association of Nuclear Medicine, EANM.

K. Britton

Departments of Radiology and Nuclear Medicine, The London Clinic,

20 Devonshire Place, London W1G 6BW, UK 


\subsection{IAEA}

For 25 years, I undertook between one to three annual mainly teaching missions abroad for the IAEA in many different countries. As a result and with their support over 100 post-graduate doctors from overseas came to us. They undertook and almost all passed the MSc of the University of London. They are mostly now Heads of Nuclear Medicine departments around the world, for example Drs Mike Rutland in New Zealand, Simon Gruenewald in Australia, Vaseem Chengazi in USA, Husein Kartamihardja in Indonesia, Ng Chensiew in Malaysia, Kerim Sonmezoglu in Turkey and Mirek Dzuik in Poland; and in the UK, included Dr Jamshed Bomanji, who was our longest and most active resident, Dr now Professor Sobhan Vinjamuri, Dr Hikmat Jan and Dr Lorenzo Biassoni. Several British residents and many other short and longer term visitors including Dr now Professor Adil Al Nahhas joined us. Commonwealth scholars also made their mark including Professor Ajit Padhy who became Head of Life Sciences at the IAEA. There were $9 \mathrm{PhDs}$ doctorates on different aspects of the department's research. Among other innovative work, Kishor Solanki and I developed Infection imaging with Tc-99m Ciprofloxacin 'Infecton'. Ciprofloxacin binds specifically to dividing bacteria including Mycobacteria. It was patented through the government's British Technology Group, BTG (now a stock market quoted company). The IAEA supported a multi-centre study in eight countries from Indonesia to Argentina. Over 1000 patients were recruited. The results were excellent and published by the IAEA and elsewhere. Infecton was taken over by the Canadian company DraxImage. Kishor Solanki subsequently joined the IAEA.

\subsection{IRCF}

Dr Marie Granowska joined the department in 1976 supported by the Wellcome Foundation to develop non-invasive measurement of Cerebral Blood flow in $\mathrm{ml} / \mathrm{min}$ using Tc-99m Albumin or Red Cells with Cyril Nimmon's computer programmes. She showed that Cerebral Blood flow improved in Professor John Lumley's patients with carotid artery disease after extra-cranial intra-cranial bypass surgery.

The ICRF supported her to undertake clinical research using the monoclonal antibodies which they provided and which Steve Mather radio-labelled. She continued at St Barts becoming a Reader in Nuclear Medicine of the University of London, except for 1 year when she was locum Consultant at the Middlesex Hospital in 1981, while Dr now Professor Peter Ell was in Berne. ICRF also supported technical staff notably Ms Sally Bentley and Mr Greg Morris, based with her at St Marks Hospital. Her research there with Professor John Northover using Tc-99m PR1A3 successfully detected recurrent colorectal cancer prior to surgery.

Her studies using Tc-99m HMFG1 or SM3 with Professor John Shepherd in Ovarian cancer and with Mr Rob Carpenter in Breast cancer were beneficial. Impalpable but involved axillary nodes were demonstrated prior to surgery. The analysis was aided by Cyril Nimmon's Probability Mapping computer programmes. All this work was presented at international meetings and published in peer-reviewed journals. 
In-111 PSMA from Cytogen Corp. USA was first used by us in Europe to evaluate Prostate cancer recurrences with Mr Vinod Nargund. Applying Melvyn Carroll's advanced image analysis, the results were very encouraging and now Ga-68 PSMA is being introduced more widely.

\subsection{EANM}

It was created partly through Professor Erkki Vauramo's 'Sauna diplomacy' at the Finnish European Congress in 1984. The presidents of the two existing societies, the Society of Nuclear Medicine, Europe, SNME and the European Society of Nuclear Medicine, ESNM were incarcerated in the hot Sauna until they had reached a provisional agreement. As President of the SNME, I chaired a subsequent 'Linking Committee', a long meeting between the senior officers of the two societies. A draft constitution separating the powers of National Delegates and individual Members was initiated and I proposed the name. The first joint meeting of the two societies was held in 1985 at the Barbican Arts Centre, London, when I was Congress President and led the organising committee. We expected 1200 and over 3000 participants came. Ms Sue Hatchard, Secretary of the BNMS and her team organised the registration and paper work, Dr Ralph McCready sorted out the exhibition and the Trade Unions; Dr Reg Jewkes dealt with the finances, Dr Peter Ell took us to the theatre to see 42nd Street, Dr Keith Harding was front of house and Dr Andrew Hilson made the music happen for the opening ceremony with the Right Honourable Edward Heath, the speaker in the interval. He spoke of how Europe was like the Orchestra, made up of many nationalities and instruments, yet working together harmoniously - times have changed! We had dinner in the Great Hall of St Bartholomew's Hospital, Fig. 11.1.

' 25 years of the EANM', contains a facsimile of the original contract. Clause 4 states that 'The European Association of Nuclear Medicine is founded in London at the European Nuclear Medicine Congress 1985 by the signatories of the contract' of whom I was one of the four, two from each Society. This makes our 1985 Congress in effect the first EANM meeting, even if it was not so titled.

\subsection{Other Collaborative Work}

Oncology with Professor Andrew Lister and Neuroendocrinology tumours, NETs, with Professor G. Michael Besser allowed us to develop or use new therapeutic agents. One of the most risky was the manufacture in house of I-131 MIBG for imaging and therapy. It required a $150{ }^{\circ} \mathrm{C}$ oil bath and large amounts of liquid I-131. It was undertaken by Laurie Hawkins and Dr Tipha Horne. We administered Y-90 Octreotide and Y-90 Lanreotide for NETs and Y-90 Bexxar anti-Lymphoma antibody for Non-Hodgkins disease. At St Marks we used P-32-PR1A3 for hepatic artery infusion for liver metastases with Angiotensin II administered to constrict the normal vessels; and intravenous P-32 labelled non-specific antibody at St Barts to target the bone marrow for the treatment of Polycythaemia. 


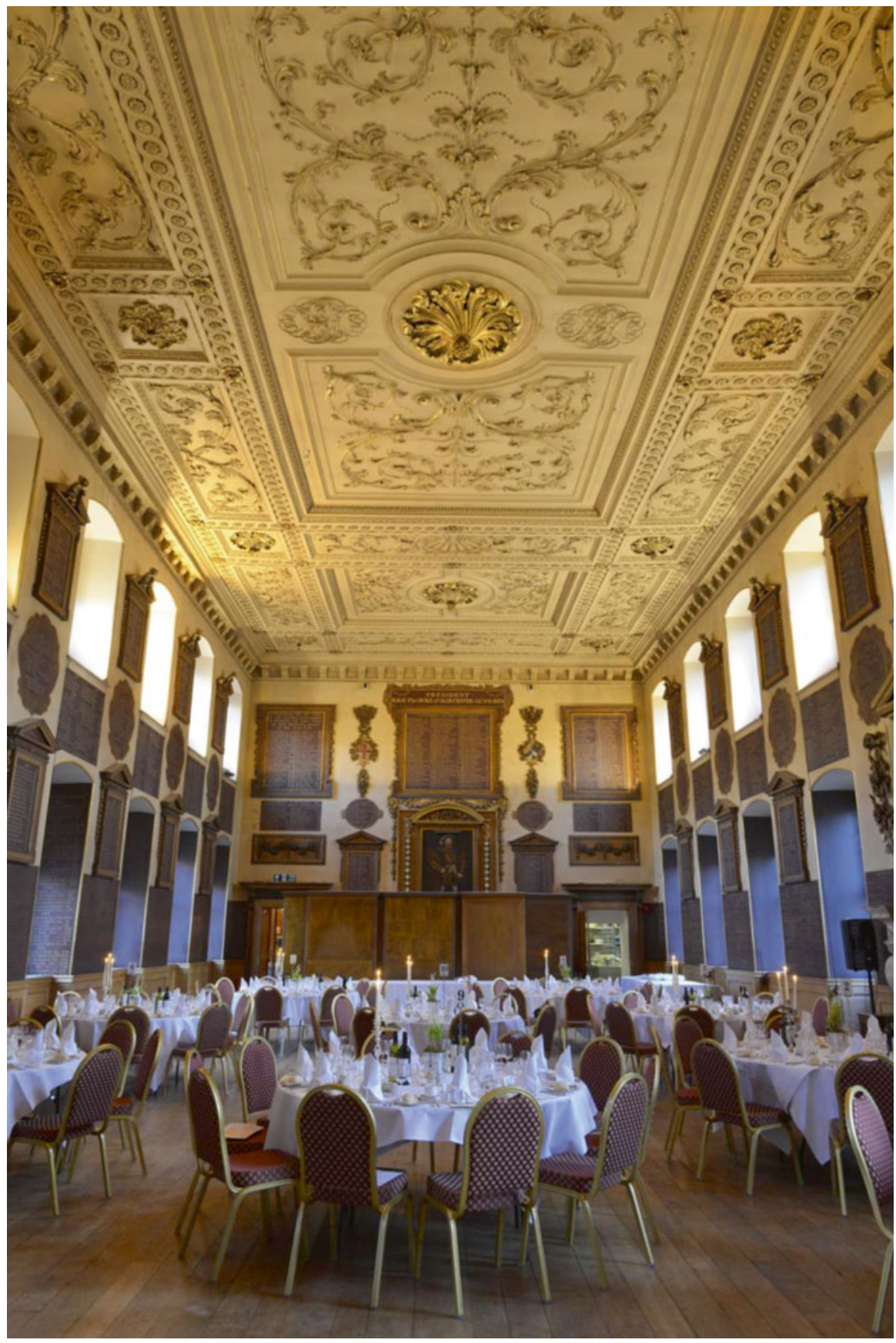

Fig. 11.1 The Great Hall at St Bartholomew's Hospital, set for dinner and overseen by Holbein's King Henry VIII at the head (Photograph courtesy of Joe D Miles, ImageCapture) 
Cardiology was keenly developed with Dr Duncan Dymond. We had the first multi-crystal Baird Atomic camera in the UK. Most daring was using Gold Au-195m (Half-life 31 s) eluted from a Mercury column with dilute Cyanide, real alchemy! Alex Elliott was the brave volunteer for the first injection with Methylene Blue standing by. The first pass images showed beautiful, moment by moment, cardiac contraction and relaxation. The short half-life enabled repeat imaging every few minutes.

Myocardial Perfusion studies with SPECT followed and in 2 years we earned $£ 1$ million for the Trust for patients coming in from around the region. The administrators said we were charging too much to their customers and made us charge less than the cost of the procedure. Of course they then complained when we were over budget. There is no space to go into the troubles caused by administrators, I will just record that when I arrived there was one administrator to four nurses, when I left there were four administrators to one nurse. When I arrived there were over 800 beds, when I left there were under 400. As a result there were patients on trolleys in passages by Casualty waiting for beds. We Physicians called them 'Bottomley' wards after the Right Honourable Mrs Virginia Bottomley, who tried to close St Barts. She failed due to the courageous efforts of Professor Michael Besser and Dame Lesley Rees.

\subsection{The Present and Future}

I was made to retire due to age 65 in 2004. After a year's interregnum presumably to save the hospital money, Dr Norbert Avril was appointed in 2005 for his PET experience. A PET/CT, which I had requested, arrived in 2008 after a 5 year delay. Dr then Professor Avril ran it. He left in 2012. Dr Hikmat Jan, who had done the MSc with us in 1997 was appointed Clinical Lead. The research and postgraduate students returned with his enthusiasm. Dr Hikmat Jan and Ms Margaret Newell, Lead Physicist at the Royal London Hospital, designed the new department. It was opened at St Barts in 2014 in the basement of the totally new building behind the King George V frontage, a listed building.

The clinical staff became jointly responsible for the Nuclear Medicine at the Royal London Hospital after the long and excellent reign of Dr Neil Garvie, who retired in 2007. Recently they provide a service for Whipps Cross and Newham Hospitals and thus serve four sites. These are fully equipped with 7 gamma cameras in total with the one PET/CT at St Barts and are linked through a Hermes system.

The current Consultant staff are: Doctors Hikmat Jan, Lead Nuclear Medicine Physician, Lorenzo Biassoni, Ewa Nowosinska, Nuclear Medicine Physicians, Athar Haroon, Ayshea Hameeduddin, Yen Zhi Tang, Arman Parsai, Nuclear Medicine/Radiologists. A further Consultant Nuclear Medicine/Radiologist is due to be appointed in September 2015. They are supported by Chief Pharmacist Dr Neil Hartman from 2003 and his staff (now supplying six hospitals) and Lead Physicist Mrs Margaret Newell from 1976 with her staff and an excellent body of technologists. There are in training six Radiology registrars and three Foundation 
Year 2 doctors. The annual work load has increased to over 4000 Myocardial Perfusion Studies and more than $2400 \mathrm{PET} / \mathrm{CT}$. There is a growing SPECT/CT demand with the other general Nuclear Medicine procedures. New therapies include Lu-177 Dotatate for NETs, Radium-223 for bone metastases and Y-90 Theraspheres for liver tumours by intra hepatic artery infusion, while the traditional Iodine-131 based therapies continue.

Under its present active leadership, Nuclear Medicine in the St Barts and the London Trust is thriving and blossoming.

Keith Britton MSc MD FRCR FRCP Emeritus Professor, University of London

Open Access This chapter is distributed under the terms of the Creative Commons AttributionNoncommercial 2.5 License (http://creativecommons.org/licenses/by-nc/2.5/) which permits any noncommercial use, distribution, and reproduction in any medium, provided the original author(s) and source are credited.

The images or other third party material in this chapter are included in the work's Creative Commons license, unless indicated otherwise in the credit line; if such material is not included in the work's Creative Commons license and the respective action is not permitted by statutory regulation, users will need to obtain permission from the license holder to duplicate, adapt or reproduce the material. 